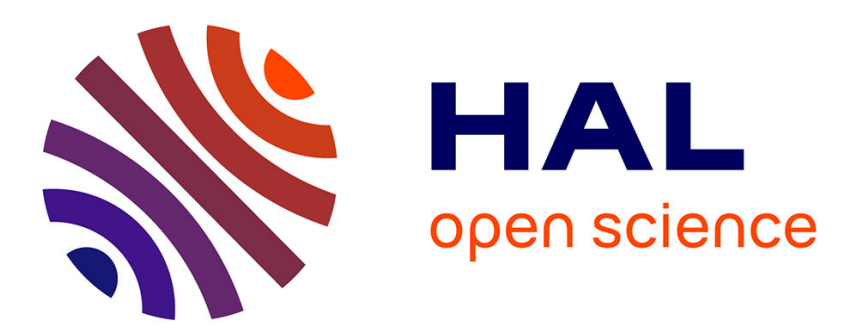

\title{
Changes in copper toxicity towards diatom communities with experimental warming
}

\author{
Soizic Morin, A.S. Lambert, E. Planes Rodriguez, A. Dabrin, Marina \\ Coquery, S. Pesce
}

\section{> To cite this version:}

Soizic Morin, A.S. Lambert, E. Planes Rodriguez, A. Dabrin, Marina Coquery, et al.. Changes in copper toxicity towards diatom communities with experimental warming. Journal of Hazardous Materials, 2017, 334, pp.223-232. 10.1016/j.jhazmat.2017.04.016 . hal-01720423

\section{HAL Id: hal-01720423 \\ https://hal.science/hal-01720423}

Submitted on 1 Mar 2018

HAL is a multi-disciplinary open access archive for the deposit and dissemination of scientific research documents, whether they are published or not. The documents may come from teaching and research institutions in France or abroad, or from public or private research centers.
L'archive ouverte pluridisciplinaire HAL, est destinée au dépôt et à la diffusion de documents scientifiques de niveau recherche, publiés ou non, émanant des établissements d'enseignement et de recherche français ou étrangers, des laboratoires publics ou privés. 
Author-produced version of the article published in Journal of Hazardous Materials, vol. 334, 2017, 223-232

The original publication is available at http://www.sciencedirect.com/

doi : 10.1016/j.jhazmat.2017.04.016

\section{Changes in copper toxicity towards diatom communities with experimental warming}

Soizic Morin ${ }^{1 *}$, Anne Sophie Lambert ${ }^{2}$, Elena Planes Rodriguez ${ }^{1}$, Aymeric Dabrin ${ }^{2}$, Marina Coquery ${ }^{2}$,

Stephane Pesce ${ }^{2}$

${ }^{1}$ Irstea, UR EABX, 50 avenue de Verdun, 33612 Cestas cedex, France

${ }^{2}$ Irstea, UR MALY, 5 rue de la Doua, CS 70077, 69626 Villeurbanne Cedex, France

${ }^{*}$ Correspondence author: E-mail: soizic.morin@irstea.fr 
Highlights

- Effects of $\mathrm{Cu}$ and temperature on biofilms were investigated over 6 weeks

- Experimental warming modified diatom community structure

- Cu exposure inhibited algal growth and selected for diatom species

- Combined stressors generally acted antagonistically

\section{Abstract}

Biological communities in aquatic environments most commonly face multiple stress, where natural and anthropogenic stressors often act jointly. Their interactions are most easily assessed using short cycle organisms such as periphytic diatoms.

In this experiment, we analyzed the combined effects of copper exposure and warming on diatom successions over 6 weeks. Natural biofilm collected in winter was left to grow in mesocosms exposed or unexposed to realistic $\mathrm{Cu}$ concentrations at four different temperatures. Separate and joint impacts of the two stressors were determined through structural and functional endpoints.

Both temperature and copper influenced the biological responses; their interaction, when significant, was always antagonistic. Diatom communities gradually changed with rising temperature. Under copper exposure, the dominant Planothidium lanceolatum was superseded by Achnanthidium exiguum, which accounted for about $70 \%$ relative abundance in the warmest conditions $\left(18-23^{\circ} \mathrm{C}\right)$. Tolerance to copper was derived from dose-response curves based on photosynthesis inhibition. $\mathrm{Cu}$ induced community tolerance was always found, but it decreased with warming and time.

Biodiversity loss associated with lower $\mathrm{Cu}$ tolerance under combined $\mathrm{Cu}$ exposure and increasing temperatures evidences the major influence of cumulative stressors on aquatic health. These results highlight the crucial interplay between environmental stressors, which are expected to intensify with climate change.

Keywords: Biofilm; Interaction; Metal; PICT; Temperature 
Author-produced version of the article published in Journal of Hazardous Materials, vol. 334, 2017, 223-232 The original publication is available at http://www.sciencedirect.com/ doi : 10.1016/j.jhazmat.2017.04.016

\section{Introduction}

Water pollution and the protection of water resources and hydro-ecosystems are global issues of international concern. Forecasting threats to aquatic biodiversity due to multiple natural and anthropogenic stressors remains challenging, in particular in the context of global change [1]. Among aquatic organisms, the importance of periphytic microbial communities (biofilms) is widely recognized for the essential ecological functions they perform (primary production, nutrient cycling, etc.) and their capacity to respond quickly to environmental stressors. Periphytic diatoms, which compose a large proportion of biofilms, have accordingly been included in water quality monitoring for some years, and are used worldwide as biological indicators of hydrosystem health [for a review, see 2].

In running waters, seasonality causes variability in diatom community composition. Rapid reproduction and recolonization of microorganisms favor a community's resilience and ability to resist environmental disturbances [3]. Seasonal successions in diatom communities are annual cyclic processes that depend closely on environmental fluctuations [e.g. in water temperature: 4, 5]. In temperate streams, temporal community patterns show monthly variations in the abundance ranking of diatom taxa and seasonal species turnover. This is because taxonomic composition, from an initial pool of species, is influenced by competition, dispersion and the time-dependent differential emergence of species from dormant propagules. Community structure and diversity will thus differ according to the sampling time frame. Soininen and Eloranta [6] found that the greatest changes in diatom relative abundances between months coincided with the warm season.

In vineyard areas where copper $(\mathrm{Cu})$ is widely used against grapevine diseases (e.g. powdery mildew and botrytis bunch rot), the local catchment basins have become gradually contaminated with $\mathrm{Cu}$ from up- to downstream [7]. The use of copper-based fungicides for vineyard protection is expected to increase in the future, with incentives for organic practices. Since diatom species have diverse amplitudes of tolerance to metals [e.g. 8, 9], Cu exposure is thought to modify community composition towards less sensitive species. Previous studies have demonstrated that an environmentally realistic 15-30 $\mathrm{g} \cdot \mathrm{L}^{-1} \mathrm{Cu}$ contamination selects for metal-tolerant diatom species under laboratory conditions [10-14], and in the Meuse River at even lower concentrations [below 10 $\mathrm{gg} \cdot \mathrm{L}^{-1}, 15$ ]. Tlili et al. [16] showed that species selection resulting from chronic Cu exposure under laboratory conditions promoted microalgal tolerance to $\mathrm{Cu}$ assessed through photosynthetic efficiency, in line with the pollution-induced community tolerance (PICT) concept [17]. 
Author-produced version of the article published in Journal of Hazardous Materials, vol. 334, 2017, 223-232 The original publication is available at http://www.sciencedirect.com/

doi : 10.1016/j.jhazmat.2017.04.016

Anthropogenic stressors such as Cu may act synergistically or antagonistically with natural factors, depending on the period of the year and associated temperature variations. Boivin et al. [18] demonstrated that warmer water temperatures promoted higher tolerance of periphytic bacterial communities to copper. They assumed an accelerated PICT acquisition by temperature-induced physiological enhancement. Similarly, Faburé et al. [19] found that heterotrophic microbial communities from biofilms collected in winter were less copper-tolerant than in other seasons. Bonet et al. [20] highlighted seasonal variations in periphytic functional responses (antioxidant enzyme activities) over the year, with an increase in biomarker responses during the summer. Focusing on structural impacts, Barranguet et al. [21, 22] exposed mature biofilms collected in Dutch rivers to copper in laboratory conditions. Cu decreased the algal biomass of biofilms collected in spring (at a water temperature of $11.5^{\circ} \mathrm{C}$ ), but did not affect diatom species composition [21]. Conversely, summer biofilms $\left(19.5^{\circ} \mathrm{C}\right)$ were more strongly impacted by $\mathrm{Cu}$, with a significant reduction in biomass and a shift in algal composition from diatoms to a proliferation of cyanobacteria [22]. Their work emphasizes that the temperature at which experiments are carried out may lead to contrasting responses of diatoms to $\mathrm{Cu}$ exposure. Changes in temperature over the year will support increased abundance of taxa whose thermal optima match the seasonal levels of temperature, but which may be less tolerant to metals: conversely, $\mathrm{Cu}$-induced selection may narrow the range of species with optimal temperature spectra. From field surveys in a cadmium/zinc-contaminated basin, Morin et al. [23] demonstrated that metals caused a decrease in diatom diversity that was more dramatic during very hot $\left(6-11^{\circ} \mathrm{C}\right.$ higher than average) than cooler summers. Identifying the periods when diatom communities are more vulnerable to toxic contamination can thus help gain a fuller understanding of how river ecosystems respond to multistress. Such knowledge will have direct implications for improving diatom-based monitoring of water quality.

In this context, we conducted a 6-week experiment in running water laboratory mesocosms. Our objectives were to assess diatom community changes under rising temperatures and copper exposure, alone and in combination, and to correlate those taxonomic modifications which changes in community tolerance towards copper, using a PICT approach. To reach these goals, we examined the response to a realistic $\mathrm{Cu}$ exposure of stream diatom communities sampled in winter, under a gradient of low to high water temperatures (four levels from 8 to $23^{\circ} \mathrm{C}$ ). These temperatures were selected to represent typical conditions of winter, spring, summer and heatwave in the area. Due to the experimental design used, community structure was expected to change with increasing temperatures: 
Author-produced version of the article published in Journal of Hazardous Materials, vol. 334, 2017, 223-232 The original publication is available at http://www.sciencedirect.com/

doi : 10.1016/j.jhazmat.2017.04.016

from a dominance of cold water species already abundant in the inoculum, the community would likely shift towards higher abundances of species, expected to be less numerous, with broader ecological amplitudes, i.e. withstanding wide temperature variations (meta- to eurythermal taxa). Under $\mathrm{Cu}$ contamination, we expected a decrease in species richness and diversity, more pronounced with higher temperatures as the consequence of cumulated stressors of different natures. Interactive effects of the two stressors on Cu tolerance were expected, resulting from the co-selection of species with broader ecological amplitudes.

\section{Materials and methods}

\subsection{Experimental design}

The experiment was conducted in 24 independent glass mesocosms $(20 \mathrm{~L})$ over 6 weeks. Drilled groundwater, adjusted for conductivity and nutrient concentrations, was recirculated in each mesocosm $\left(\sim 1.2 \mathrm{~L} \cdot \mathrm{min}^{-1}\right)$, as described in Lambert et al. [24]. Eight experimental conditions were tested in triplicate, corresponding to the combination of two $\mathrm{Cu}$-exposure treatments (noCu and $\mathrm{Cu}=15 \mu \mathrm{g} \cdot \mathrm{L}^{-1}$ nominal concentration, supplied as $\left.\mathrm{CuSO}_{4} \cdot 5 \mathrm{H}_{2} \mathrm{O}\right)$ and four temperature levels. The temperatures selected were maintained using water baths: $8^{\circ} \mathrm{C}, 13^{\circ} \mathrm{C}, 18^{\circ} \mathrm{C}$ and $23^{\circ} \mathrm{C}$. Light was provided in a 13:11 h light/dark photoperiod by high-pressure sodium lamps delivering 3500 lux.

All the experimental mesocosms were seeded once at the beginning of the experiment with a biofilm inoculum from the Morcille River (Beaujolais, Eastern France) at its upstream pristine site, collected on cobbles in February 2012 and suspended in river water. Glass slides $(7.6 \mathrm{~cm} \times 2.5 \mathrm{~cm})$ suspended just below the water surface of each mesocosm were used as artificial substrates for biofilm colonization. Cu concentrations were chosen to be realistic for the Morcille River basin [7]. The four water temperatures were meant to span the thermal conditions found in the river, based on high-frequency monitoring values in this catchment basin for the 2011-2013 interval (midday temperatures measured daily, unpublished data). The lowest temperature used $\left(8^{\circ} \mathrm{C}\right)$ was the temperature at the time of in situ biofilm sampling and corresponds to the site's average water temperatures at the end of winter (March: $8.6 \pm 2.1^{\circ} \mathrm{C}$ ). The other water temperatures tested are found in spring (May-June average: $12.9 \pm 1.5^{\circ} \mathrm{C}$ ), in fall (September-October: $13.8 \pm 1.9^{\circ} \mathrm{C}$ ), in summer (July-August: $17.5 \pm 2.9^{\circ} \mathrm{C}$ ), and during hot periods at the end of the summer (frequent peaks above $25^{\circ} \mathrm{C}$ in the second half of August). 
Author-produced version of the article published in Journal of Hazardous Materials, vol. 334, 2017, 223-232 The original publication is available at http://www.sciencedirect.com/

doi : 10.1016/j.jhazmat.2017.04.016

Water was renewed weekly to ensure constant exposure levels and to limit nutrient depletion. Water analyses were performed before and after each water change. Physicochemical parameters $(\mathrm{pH}$, conductivity and dissolved oxygen) were measured by a multi-parameter probe (WTW, Germany). Concentrations of orthophosphates, nitrates, nitrites, ammonium, silica and dissolved organic carbon (DOC) were determined following French standards (NF EN ISO 6878, NF EN ISO 10304, NF EN 26777, NF T 90-015-2, NF T 90-007 and NF EN 1484). Dissolved Cu concentrations were analyzed using inductively coupled plasma mass spectrometry (ICP-MS X Series II, Thermo Electron), after filtration of the water sample ( $0.45 \mu \mathrm{m}$ PVDF filter, Whatman) and acidification to $0.5 \%(\mathrm{v} / \mathrm{v})$ of nitric acid (14M Suprapur, Merck). The limit of quantification for $\mathrm{Cu}\left(0.05 \mu \mathrm{g} \cdot \mathrm{L}^{-1}\right)$ was calculated according to the French standard NF T 90-210 [25]. Blanks and certified reference material (Environment Canada, TM 27-3, Lake Ontario natural water, Cu concentration of $\left.6.61 \pm 0.61 \mu \mathrm{g} \cdot \mathrm{L}^{-1}\right)$ were systematically used to control analytical accuracy $(94 \%)$ and precision $(7 \%)$. Water quality was stable throughout the experiment and between treatments (Table 1), and dissolved Cu was below $0.3 \mu \mathrm{g} \cdot \mathrm{L}^{-1}$ and $13.2 \pm 5.5 \mu \mathrm{g} \cdot \mathrm{L}^{-1}$ in the noCu and $\mathrm{Cu}$ treatments, respectively. Effective temperatures, measured every hour with data loggers $(\mathrm{HOBO} \circledast$ Pendant Temperature/Light, Prosensor), were $8.1( \pm 0.7), 12.8( \pm 0.7)$, $18.4( \pm 0.4)$ and $22.9( \pm 0.3)^{\circ} \mathrm{C}$ over the time course of the experiment.

Treatments were further labeled $\mathrm{Cu}-X$ and noCu- $X$, for copper exposure or absence thereof at incubation temperature $X$.

\subsection{Sample collection, preparation and analysis}

Biofilm was sampled weekly from Weeks 2 to 6 in each mesocosm, scraped off carefully and resuspended in 1:10 (v/v) mineral:ultrapure water (Volvic mineral water, France; Milli-Q ultrapure water, Millipore). A PhytoPAM instrument ( $\mathrm{H}$. Walz $\mathrm{GmbH}$, Germany) was used to quantify the contribution of diatoms to chlorophyll a concentration ( $n=3$ per treatment) at each sampling time.

To evaluate the acquisition of tolerance to copper in the different treatments on the last two sampling dates ( 4 and 6 weeks), we used samples of the biofilm suspensions to perform PICT measurements [17] based on the inhibition of chlorophyll a fluorescence. Biofilm suspensions were aliquoted in individual flasks before being exposed to six increasing Cu concentrations (semi-exponential dilution series of Cu ranging from 0 to $105 \mu \mathrm{g} \cdot \mathrm{L}^{-1}$, final concentrations) for $3 \mathrm{~h}$ at ambient temperature $\left(23^{\circ} \mathrm{C}\right)$. 
Author-produced version of the article published in Journal of Hazardous Materials, vol. 334, 2017, 223-232 The original publication is available at http://www.sciencedirect.com/

doi : 10.1016/j.jhazmat.2017.04.016

Chlorophyll a fluorescence was measured after a 30min dark adaptation. The effective copper concentrations causing a $50 \%$ decrease in fluorescence $\left(\mathrm{EC}_{50}\right)$ were calculated from the doseresponse curves fitted using REGTOX (v.7.0.7, ( E Eric Vindimian, 2001) macro for Microsoft Excel ${ }^{\mathrm{TM}}$, applying the Hill model. As biofilm biomass can affect the estimation of tolerance levels, we normalized the PICT responses per chlorophyll a concentration [as in 14, 26].

Samples were taken for diatom identification on Weeks 2, 4 and 6, and in the inoculum ( $n=3$ per treatment at each sampling date). They were digested with boiling hydrogen peroxide, then washed several times in distilled water and centrifuged. Permanent slides were then prepared (NF EN 13946), and diatom species identified according to NF EN 14407.

\subsection{Data analysis}

Changes in species composition between the inoculum and successive sampling dates were assessed by percentage turnover as in Soininen \& Eloranta [6]. Turnover was the ratio of the sum of taxa gained and lost between each sampling date and the inoculum (Week 0), to the sum of the total number of species recorded on the two dates.

We tested the interaction between Cu exposure and temperature level on the biological responses with a linear mixed-effect model. The model had two fixed factors: copper (2 levels) and temperature (4 levels), and assumed nested random effect structure for sampling date and replicates. This enabled us to highlight changes in biological responses as a function of $\mathrm{Cu}$, temperature and their interaction, discarding the significant effect of sampling time. The model was used to predict the effects of treatments on diatom biomass, diversity estimates of diatom community composition (total richness, Shannon diversity and species turnover) and the distribution of the most abundant species. We applied a $\log (x+1)$ transformation on diatom relative abundances prior to the analysis, as recommended by Májeková et al. [27]. When meaningful Cu-temperature interactions were observed, the mode of interaction was interpreted as antagonistic when the combined effect of warming and $\mathrm{Cu}$ was less than the additive effect, synergistic when the interaction amplified the impact [28].

Principal response curves [PRC; 29] were used to establish diatom community trajectories over time, depending on the temperature and whether there was exposure to $\mathrm{Cu}$. PRC is used to easily interpret multivariate responses in repeated observation design, as it summarizes in a single diagram the 
effects on a community of any treatment, and their changes over time. The technique is based on partial Redundancy Analysis, and statistical information can be obtained to describe the explanatory power of the PRC. The analyses were performed on the centered and reduced abundance matrix of the species, whose relative abundances accounted for more than $2 \%$ in at least one sample.

All statistical analyses were performed with the $\mathrm{R}$ statistical programming environment (https://cran.rproject.org), using the libraries nlme, ade4 and vegan.

\section{Results}

\subsection{Chlorophyll a}

As shown in Fig. 1, the concentration of chlorophyll a related to diatoms increased in all the treatments over time. While copper exposure produced a sharp decrease in biomass accrual $(p=0.035)$, temperature did not significantly influence the amount of chlorophyll a related to diatoms $(p=0.371)$. We note, however, that growth inhibition of diatoms in Cu-exposed mesocosms was attenuated at the highest temperatures $\left(18\right.$ and $\left.23^{\circ} \mathrm{C}\right)$, compared with cooler ones.

\subsection{Diversity estimates}

A total of 102 species were identified, of which 33 had $>1 \%$ relative abundances in at least one sample and 19 over $2 \%$. All diversity estimates were significantly influenced by experiment duration (Fig. 2). The separate and cross effects of $\mathrm{Cu}$ and temperature, predicted by linear mixed-effect models, are reported in Table 2.

From an inoculum of 40 species, a reduction in the number of species recorded over time was observed in all treatments (Fig. 2a-b). Likewise, Shannon diversity values (Fig. 2c-d) decreased from Week 0 to Week 6 . Both species richness and diversity were significantly reduced by combined copper exposure and warming $(p<0.04)$. Overall, species richness decreased as temperature rose (Fig. 2a), whereas this effect was alleviated by $\mathrm{Cu}$ alone, in particular at $8^{\circ} \mathrm{C}$ (Fig. 2b). Average Shannon values were higher under copper exposure (Fig. 2c-d), but warming acted antagonistically towards increased biodiversity loss, especially on Week 6 at the highest temperatures tested (18 and $\left.23^{\circ} \mathrm{C}\right)$. 
Author-produced version of the article published in Journal of Hazardous Materials, vol. 334, 2017, 223-232 The original publication is available at http://www.sciencedirect.com/

doi : 10.1016/j.jhazmat.2017.04.016

Changes in community structure over time were highlighted by increasing turnover (Fig. 2e-f) from Weeks 2 to 6 . Species turnover was exacerbated at higher temperatures $(p=0.013)$, indicating lower persistence. Neither copper exposure nor combined $\mathrm{Cu}$ and warming significantly affected turnover ( $p=0.183$ and 0.254 respectively).

\subsection{Changes in species composition}

Detailed distributions of the dominant species (representing more than $5 \%$ relative abundance in at least one sample) over time in all treatments are given in Appendix A. The PRC (Fig. 3) highlighted unequivocal trajectories of community variation over time, where all the treatments clearly deviated from the control succession (noCu-8). $54.3 \%$ of the total variance of the dataset was explained by the treatments. In the absence of copper, the curves diverged increasingly from the zero effect trajectory with increasing temperatures. Cu exposure amplified the distance from the control line for all temperatures, and differences between temperatures were visible in Cu treatments. In particular, the curves tended to stabilize in most conditions from Weeks 4 to 6 : the trajectory went farther in the $\mathrm{Cu}$ exposed communities grown at $23^{\circ} \mathrm{C}$. Table 2 shows the positive or negative contributions of the factors tested $(\mathrm{Cu}$, temperature, date) and their significance in the linear mixed-effects models performed on the relative abundances of the 19 most abundant species.

On the right $Y$-axis, in Fig. 3, are shown the weights of each diatom species for the response pattern of the PRC. Among the species correlated with the positive effect values, Navicula gregaria and Nitzschia linearis had low abundances $(<4 \%)$ in the inoculum and were impacted by both temperature and $\mathrm{Cu}(p<0.001$, Table 2). Warming removed the negative impact on their growth observed under copper exposure alone. In contrast, Planothidium lanceolatum (12\% in the inoculum) developed over time to achieve marked dominance in all the noCu treatments (reaching ca.60\%), but its growth was strongly impaired under combined exposure to copper and higher temperatures $(p=0.029)$.

Around the zero values of the $Y$-axis of the PRC are grouped species of low abundance (generally below $5 \%$ ) and/or species whose presence could not be readily explained by Cu exposure or temperature.

The lower half-panel (negative values) shows the species whose abundances significantly increased during the experiment, compared with noCu-8 communities. In general, these species were favored by 
Author-produced version of the article published in Journal of Hazardous Materials, vol. 334, 2017, 223-232 The original publication is available at http://www.sciencedirect.com/

doi : 10.1016/j.jhazmat.2017.04.016

copper exposure (Table 2), and no interaction between copper and temperature was found. The species that was most discriminating was Achnanthidium exiguum, which was almost absent from the inoculum $(<0.5 \%)$ and grew little in the noCu treatments at the lowest temperature. Increasing temperatures promoted its development over 6 weeks ( $p<0.0001$ ), up to $20 \%$ in noCu-23. A. exiguum was distinctly favored under copper exposure $(p=0.0008)$, and reached more than $70 \%$ in $\mathrm{Cu}-18$ and Cu-23. Most of the other taxa correlated with negative $Y$-axis values (Cocconeis euglypta, $C$. placentula and Reimeria sinuata), slightly decreased over time, but were also favored under $\mathrm{Cu}$ exposure $(p \leq 0.01)$. For these species, the effect of temperature alone was negligible $(p \geq 0.137)$.

\subsection{Variations in community tolerance to copper with $\mathrm{Cu}$ pre-exposure and increasing temperatures}

After 4 weeks of colonization, the toxicity tests from the PICT approach revealed that fluorescence was halved in Cu-8 communities by a copper concentration 100 times higher than in noCu biofilms (Fig. 4). Normalized $\mathrm{EC}_{50}$ values of previously Cu-exposed communities were always higher than those of noCu at similar temperatures. In both $\mathrm{Cu}$ and noCu biofilms, tolerance towards copper significantly decreased over time and with warming. The $\mathrm{EC}_{50}$ values diminished as temperature increased in the Cu communities, with a 10-fold difference on Week 4, and a 60-fold difference on Week 6 .

\section{Discussion}

\subsection{Environmental realism of the experimental approach}

Laboratory scales can be extrapolated to natural scales when experiments are designed so that the response studied is accurate and environmentally realistic [30]. In this work, we inoculated a suspension of diatom propagules for the colonization of glass substrates. Periphytic organisms cannot select the environment they colonize, and their microscopic size compared with the system reduces spatial scale-dependence, permitting the transposition of our results to spatial and temporal scales greater than our mesocosm and time frames. Compared with diverse previous records in the River Morcille, diatom species composition of both noCu and $\mathrm{Cu}$ treatments matched field communities (Appendix B). All species were found in fairly comparable abundances in one or more field-collected samples, but differing communities were found between the experimental treatments as a 
Author-produced version of the article published in Journal of Hazardous Materials, vol. 334, 2017, 223-232 The original publication is available at http://www.sciencedirect.com/

doi : 10.1016/j.jhazmat.2017.04.016

consequence of both environmental conditions, including the abrupt temperature changes we imposed (compared to gradual warming in nature), and biological interactions. Species similarities with those in the field highlighted that our experimental conditions allowed the development of diversified communities that were maintained over time, retaining ecological realism in the biological response.

The complexity of the experimental model is crucial when dealing with combined stressors, as it governs the type of interaction observed [31]: synergistic effects are better observed using simplified biological models, whereas the impacts tend to be modulated or masked in communities.

Nevertheless, our experimental conditions may still have overlooked important processes likely to mitigate, in natural conditions, the responses we observed, owing to environmental variability and biological complexity. In particular, the experimental set-up did not account for spatial heterogeneity (metacommunities) and limited immigration and emigration of species that are important drivers of the response of communities under metal stress [11]. Because of these limitations inherent to laboratory manipulation, we must consider the responses observed rather as likely trends, and may expect lower amplitude in natural periphytic communities.

\subsection{Chronic exposure to copper and warming induce species selection in the community}

Copper exposure inhibited growth (Table 2) and had a major influence on diatom successions (Fig. 3). The impact of $\mathrm{Cu}$ towards diatom community structure has been largely described in the literature, and our results support previous evidence of a $\mathrm{Cu}$-induced decrease in algal biomass or species selection [reviewed by e.g. 32]. While several species gradually disappeared in the Cu-exposed mesocosms, taxa belonging to the Achnanthidiaceae became dominant $(76 \pm 6 \%)$, confirming this family's tolerance to copper [33]. Interestingly, the same species ( $A$. exiguum, $A$. minutissimum and $P$. lanceolatum) cooccurred in our mesocosms as in the Cu-contaminated cores of Lake Orta analyzed in this study [33].

As expected, temperature also appeared to be an important driving force for some species, originated from the winter inoculum. Certain species intolerant of elevated temperature disappeared in warmer water, whereas others with broader temperature spectra still occurred in the community. These changes in community structure, as shown in Fig. 3, were also reflected in enhanced turnover with temperature (Table 2). Our results are in disagreement with those of earlier work arguing that biofilms exposed to warmer temperatures are characterized by greater biomass accrual [34] or higher species richness and diversity [35]. Temperature rise favored only $A$. exiguum, from weeks $2-4$, but inhibited 
Author-produced version of the article published in Journal of Hazardous Materials, vol. 334, 2017, 223-232 The original publication is available at http://www.sciencedirect.com/

doi : 10.1016/j.jhazmat.2017.04.016

the growth of several species present. Consequently, species richness decreased more over time with increasing temperatures, and species turnover on Week 6 was highest at $23^{\circ} \mathrm{C}$ (Fig. 2). In the inoculum, A. exiguum was extremely sparse $(0.5 \%)$ and did not increase in the controls at the lowest temperatures ( 8 and $13^{\circ} \mathrm{C}$ ), but it grew moderately at higher temperatures to reach abundances of ca. $20 \%$ at $23^{\circ} \mathrm{C}$ at the end of the experiment. $A$. exiguum is eurythermal [4], meaning that it tolerates wide ranges of temperatures (higher than $15^{\circ} \mathrm{C}$ ), consistent with our results. In the Süßwasserflora von Mitteleuropa [36], A. exiguum is reported to grow massively under exceptional conditions such as in aquarium tanks, and is able to withstand temperatures exceeding $40^{\circ} \mathrm{C}$ in hot springs. This species is found quite commonly in tropical areas $[37,38]$. Some of the subdominant species were early colonizers indifferent to temperature increase, such as Cocconeis species [in agreement with 35], or Achnanthidium minutissimum and Reimeria sinuata that are mentioned as eurythermal taxa in Lowe [4]. They were found at similar abundances along the thermal gradient, but logically, they did not maintain their growth for the overall course of the experiment.

Diatoms were also influenced by the combined effects of copper exposure and warming. The temporal succession patterns over 6 weeks, and the time-dependent interactive effects observed experimentally, emphasize the importance of considering the effect of time frames in the distribution of diatom species (Fig. 3). Species coexistence in natural diatom communities at large geographic scales (regional) is mostly neutral coexistence [39], and competitive exclusion is seldom evidenced [40]. Our data suggest that the mechanisms of diatom successions at a finer spatial grain (local) also included competition under the joint control of metal exposure and increased temperatures. This was highlighted in particular by the coexistence dynamics of $P$. lanceolatum and A. exiguum (Appendix A). Cu-exposure repressed species successions to produce communities closer to the inoculum during the first four weeks of the experiment (Appendix B), compared to the noCu treatment. Competition is thought to be keenest among species sharing similar traits, such as these two. In noCu conditions, $P$. lanceolatum was one of the first taxa to colonize the substrates (strong increase in abundances in the first weeks), and was able to withstand wide temperature ranges. It was the dominant species in the noCu treatment at all the temperatures tested, averaging $58 \%$ on Week 6 with optimal growth at $13^{\circ} \mathrm{C}$ ( $>70 \%)$. This cosmopolitan species is generally a pioneer in new environments, and is seasonally optimal in spring and fall, consistent with its dominance at $13^{\circ} \mathrm{C}$. In the absence of copper and at lower temperatures, the growth of $A$. exiguum was restricted by the massive development of $P$. lanceolatum, whereas they coexisted at the warmest temperatures from Week 4. In the Cu-exposed mesocosms, 
Author-produced version of the article published in Journal of Hazardous Materials, vol. 334, 2017, 223-232 The original publication is available at http://www.sciencedirect.com/ doi : 10.1016/j.jhazmat.2017.04.016

their coexistence was also observed at $8-13^{\circ} \mathrm{C}$. However, under chronic $\mathrm{Cu}$ exposure and warmer temperatures $\left(18\right.$ and $\left.23^{\circ} \mathrm{C}\right), P$. lanceolatum grew poorly, and was clearly outcompeted by $A$. exiguum. The latter was clearly favored by $\mathrm{Cu}$, and by the combination of copper and higher temperatures, making it the dominant species (averaging $72 \%$ at 18 and $23^{\circ} \mathrm{C}$ ).

\subsection{Cu and temperature-induced changes in species composition affect community tolerance towards} copper

The existence of significant interactions between the two types of stressors on diatom responses over time was supported by the high number of cross-effects identified (Table 2). Like for Alsterberg and Sundbäck [28], who studied intertidal communities exposed to both experimental warming $\left(\mathrm{a} 4^{\circ} \mathrm{C}\right.$ elevation of ambient spring temperature) and copper pyrithione $\left(0.2 \mathrm{ngCu} \cdot \mathrm{g}^{-1}\right.$, dry weight sediment), all interactive effects between temperature and toxicant were antagonistic. Here, copper exposure was generally found to affect the structural responses (positively or negatively), with increasing temperatures removing or reducing Cu effects. Interactive effects of the two stressors were also observed at a functional level. Corroborating PICT assumptions [17], tolerance to $\mathrm{Cu}$ was always higher in communities previously exposed to the metal than in noCu communities. However, warming did not accelerate PICT, either in $\mathrm{Cu}$ or in noCu communities, conflicting with the findings of Boivin et al. [18] for bacterial communities. On the contrary, higher temperature instead increased their sensitivity (Fig. 4).

The modulation of copper toxicity by temperature during chronic exposure may be both direct and indirect. It may be explained by temperature-induced changes in metal bioavailability, as well as biological tradeoffs [31]. Oukarroum et al. [41] suggested that copper bioavailability may be reduced by changes in speciation at warmer temperatures. Here, intracellular accumulation was not enhanced by temperature [see 24 for details], as also found by Sbihi et al. [42] using higher exposure concentrations. Indeed, they observed no increase in Cu biosorption by $P$. lanceolatum (one of the dominant species here) over a $15-40^{\circ} \mathrm{C}$ range of temperatures, for concentrations ranging from 0.1 to $1.6 \mathrm{mgCu} \cdot \mathrm{L}^{-1}$. The mechanism of species selection over time by temperature and/or toxicant exposure more likely explains the patterns observed in the PICT response: under chronic Cu exposure, we found the highest tolerance in $\mathrm{Cu}-8$ communities where the number of species and Shannon diversity were at their highest values, supporting the hypothesis that stress tolerance is underpinned by 
Author-produced version of the article published in Journal of Hazardous Materials, vol. 334, 2017, 223-232 The original publication is available at http://www.sciencedirect.com/

doi : 10.1016/j.jhazmat.2017.04.016

biodiversity and species niche complementarity. This is in line with the concept of ecological insurance [43], whereby more diverse communities are more likely to contain species that can cope with environmental stress. Contrastingly, taxonomically-related species ( $P$. lanceolatum and A. exiguum) co-dominated the community in all other treatments, correlated with exacerbated sensitivity towards $\mathrm{Cu}$ (Appendix A, Figure 4). Temperature-induced selection thus scaled down tolerance acquisition, highlighting the fact that species with wider thermal spectra may not be co-tolerant to toxicants. The relationship between the dominance by $P$. lanceolatum and $A$. exiguum with lower PICT was also highlighted by the fact that they increased in abundance between Weeks 4 and 6 . Given that tolerance acquisition is in part the consequence of changes in community structure, it is highly plausible that our PICT responses resulted from selection of these two species, driven by both stressors. The $\mathrm{EC}_{50}$ decreases were exponentially correlated with their cumulated percentages $\left(R^{2}=0.69, p<0.0001, n=16\right)$.

\section{Conclusion}

This experimental investigation of diatom successions under copper stress and ranging temperatures confirms the major influence of environmental conditions on community successions, highlighting the importance of combined natural and anthropic stressors. In this study, most diatom responses were affected by either copper exposure or warming, and interactions were observed as expected. Unequivocal trajectories in community assemblages were amplified over time, with Cu exposure and increasing temperatures. The integrity of species co-existence was modified, potentially predictive of consequences of freshwater warming.

Our PICT results confirmed that community structure strongly affects ecosystem vulnerability, such as primary production, thanks to photosynthetic processes. Exacerbated impacts can therefore be expected in streams exposed to $\mathrm{Cu}$ inputs when temperatures increase, i.e. in hotter seasons, or in temporary rivers where metals could become more concentrated as water levels decrease.

From a biomonitoring perspective, this works supports current standards applied for the determination of diatom indices, in which it is recommended to study diatom communities during low flow, warm, periods. We found higher vulnerability to copper contamination in the mature (6-weeks old) periphytic community at warmer temperatures corresponding to summer conditions, confirming that seasonal conditions should also be lent more attention in water quality assessment, in the case of toxic contaminations. 


\section{Acknowledgments}

We are grateful to Aurélien Jamoneau (Irstea Bordeaux) who helped in analyzing the data. The authors also thank Bernard Motte, Christophe Rosy, Bernadette Volat and Josiane Gahou (Irstea Lyon-Villeurbanne) for technical support, and ATT for language editing. We also acknowledge the four anonymous reviewers for their insightful comments and suggestions on the previous version of the manuscript. This study was carried out in the framework of the Cluster of Excellence COTE and the Long-Term Ecological Research (LTER) Zone Atelier du Bassin du Rhône (ZABR).

\section{Cited references}

[1] J. Artigas, G. Arts, M. Babut, A.B. Caracciolo, S. Charles, A. Chaumot, B. Combourieu, I. Dahllöf, D. Despréaux, B. Ferrari, N. Friberg, J. Garric, O. Geffard, C. Gourlay-Francé, M. Hein, M. Hjorth, M. Krauss, H.J. De Lange, J. Lahr, K.K. Lehtonen, T. Lettieri, M. Liess, S. Lofts, P. Mayer, S. Morin, A. Paschke, C. Svendsen, P. Usseglio-Polatera, N. van den Brink, E. Vindimian, R. Williams, Towards a renewed research agenda in ecotoxicology, Environ. Pollut. , 160 (2012) 201-206.

[2] S. Morin, N. Gómez, E. Tornés, M. Licursi, J. Rosebery, Benthic diatom monitoring and assessment of freshwater environments: Standard methods and future challenges, in: A.M. Romaní, H. Guasch, M.D. Balaguer (Eds.) Aquatic Biofilms: Ecology, Water Quality and Wastewater Treatment, Caister Academic Press, 2016, pp. 111-124.

[3] C.R. Townsend, S. Dolédec, M.R. Scarsbrook, Species traits in relation to temporal and spatial heterogeneity in streams: a test of habitat templet theory, Freshwat. Biol., 37 (1997) 367-387. [4] R.L. Lowe, Environmental requirements and pollution tolerance of freshwater diatoms, US Environmental Protection Agency, Environmental Monitoring Series, Cincinnati, Ohio, 1974.

[5] R. Patrick, The effects of increasing light and temperature on the structure of diatom communities, Limnol. Oceanogr., 16 (1971) 405-421.

[6] J. Soininen, P. Eloranta, Seasonal persistence and stability of diatom communities in rivers: are there habitat specific differences ?, Eur. J. Phycol., 39 (2004) 153-160.

[7] M. Rabiet, M. Coquery, N. Carluer, J. Gahou, V. Gouy, Transfer of metal(loid)s in a small vineyard catchment: contribution of dissolved and particulate fractions in river for contrasted hydrological conditions, Environ. Sci. Pollut. Res., 22 (2015) 19224-19239.

[8] T. Bere, T. Mangadze, T. Mwedzi, Variation partitioning of diatom species data matrices:

Understanding the influence of multiple factors on benthic diatom communities in tropical streams, Sci. Total Environ., in press (2016).

[9] S. Morin, A. Cordonier, I. Lavoie, A. Arini, S. Blanco, T.T. Duong, E. Tornés, B. Bonet, N. Corcoll, L. Faggiano, M. Laviale, F. Pérès, E. Becares, M. Coste, A. Feurtet-Mazel, C. Fortin, H. Guasch, S. Sabater, Consistency in diatom response to metal-contaminated environments, in: H. Guasch, A. Ginebreda, A. Geiszinger (Eds.) Hdb Env Chem, Springer, Heidelberg, 2012, pp. 117-146.

[10] H. Guasch, E. Navarro, A. Serra, S. Sabater, Phosphate limitation influences the sensitivity to copper in periphytic algae, Freshwat. Biol., 49 (2004) 463-473.

[11] S. Morin, A.-S. Lambert, J. Artigas, M. Coquery, S. Pesce, Diatom immigration drives biofilm recovery after chronic copper exposure, Freshwat. Biol., 57 (2012) 1658-1666.

[12] A. Serra, N. Corcoll, H. Guasch, Copper accumulation and toxicity in fluvial periphyton: The influence of exposure history, Chemosphere, 74 (2009) 633-641.

[13] A. Serra, H. Guasch, Effects of chronic copper exposure on fluvial systems: Linking structural and physiological changes of fluvial biofilms with the in-stream copper retention, Sci. Total Environ., 407 (2009) 5274-5282.

[14] D. Soldo, R. Behra, Long-term effects of copper on the structure of freshwater periphyton communities and their tolerance to copper, zinc, nickel and silver, Aquat. Toxicol., 47 (2000) 181-189. 
[15] C. Barranguet, E. Charantoni, M. Plans, W. Admiraal, Short-term response of monospecific and natural algal biofilms to copper exposure, Eur. J. Phycol., 35 (2000) 397 - 406.

[16] A. Tlili, A. Bérard, J.-L. Roulier, B. Volat, B. Montuelle, $\mathrm{PO}_{4}{ }^{3-}$ dependence of the tolerance of autotrophic and heterotrophic biofilm communities to copper and diuron, Aquat. Toxicol., 98 (2010) 165-177.

[17] H. Blanck, S.A. Wängberg, S. Molander, Pollution-Induced Community Tolerance - A new ecotoxicological tool., in: Functional Testing of Aquatic Biota for estimating Hazards of Chemicals, Cairns J. Jr, Pratt J.R. (Eds), Philadelphia, 1988, pp. 219-230.

[18] M.-E.Y. Boivin, B. Massieux, A.M. Breure, F.P. van den Ende, G.D. Greve, M. Rutgers, W. Admiraal, Effects of copper and temperature on aquatic bacterial communities, Aquat. Toxicol., 71 (2005) 345-356.

[19] J. Faburé, M. Dufour, A. Autret, E. Uher, L.C. Fechner, Impact of an urban multi-metal contamination gradient: Metal bioaccumulation and tolerance of river biofilms collected in different seasons, Aquat. Toxicol., 159 (2015) 276-289.

[20] B. Bonet, N. Corcoll, V. Acuňa, L. Sigg, R. Behra, H. Guasch, Seasonal changes in antioxidant enzyme activities of freshwater biofilms in a metal polluted Mediterranean stream, Sci. Total Environ., 444 (2013) 60-72.

[21] C. Barranguet, M. Plans, E. van der Grinten, J.J. Sinke, W. Admiraal, Development of photosynthetic biofilms affected by dissolved and sorbed copper in a eutrophic river, Environ. Toxicol. Chem., 21 (2002) 1955-1965.

[22] C. Barranguet, F.P. van den Ende, M. Rutgers, A.M. Breure, M. Greijdanus, J.J. Sinke, W. Admiraal, Copper-induced modifications of the trophic relations in riverine algal-bacterial biofilms, Environ. Toxicol. Chem., 22 (2003) 1340-1349.

[23] S. Morin, B. Bonet, N. Corcoll, H. Guasch, M. Bottin, M. Coste, Cumulative Stressors Trigger Increased Vulnerability of Diatom Communities to Additional Disturbances, Microbial Ecology, 70 (2015) 585-595.

[24] A.S. Lambert, A. Dabrin, S. Morin, J. Gahou, A. Foulquier, M. Coquery, S. Pesce, Temperature modulates phototrophic periphyton response to chronic copper exposure, Environ. Pollut. , 208, Part B (2016) 821-829.

[25] AFNOR, Qualité de l'eau - Protocole d'évaluation initiale des performances d'une méthode dans un laboratoire. NF T 90-210, in, 2009, pp. 43.

[26] A.-S. Lambert, S. Morin, J. Artigas, B. Volat, M. Coquery, M. Neyra, S. Pesce, Structural and functional recovery of microbial biofilms after a decrease in copper exposure: Influence of the presence of pristine communities, Aquat. Toxicol., 109 (2012) 118-126.

[27] M. Májeková, T. Paal, N.S. Plowman, M. Bryndová, L. Kasari, A. Norberg, M. Weiss, T.R. Bishop, S.H. Luke, K. Sam, Y. Le Bagousse-Pinguet, J. Lepš, L. Götzenberger, F. de Bello, Evaluating functional diversity: missing trait data and the importance of species abundance structure and data transformation, PLoS ONE, 11 (2016) e0149270.

[28] C. Alsterberg, K. Sundbäck, Experimental warming and toxicant exposure can result in antagonistic effects in a shallow-water sediment system, Mar. Ecol. Prog. Ser., 488 (2013) 89-101. [29] P.J. Van den Brink, C.J.F. Ter Braak, Principal response curves: analysis of time-dependent multivariate responses of a biological community to stress, Environ. Toxicol. Chem., 18 (1999) 138148.

[30] G. Englund, S.D. Cooper, Scale effects and extrapolation in ecological experiments, in: Advances in Ecological Research, Academic Press, 2003, pp. 161-213.

[31] C.M. Crain, K. Kroeker, B.S. Halpern, Interactive and cumulative effects of multiple human stressors in marine systems, Ecol. Lett., 11 (2008) 1304-1315.

[32] S. Masmoudi, N. Nguyen-Deroche, A. Caruso, H. Ayadi, A. Morant-Manceau, G. Tremblin, M. Bertrand, B. Schoefs, Cadmium, copper, sodium and zinc effects on diatoms: from Heaven to Hell - A review, Cryptogamie, Algologie, 34 (2013) 185-225.

[33] D. Ruggiu, A. Luglie, A. Cattaneo, P. Panzani, Paleoecological evidence for diatom response to metal pollution in Lake Orta (N. Italy), J. Paleolimnol., 20 (1998) 333-345.

[34] V. Diaz Villanueva, J. Font, T. Schwartz, A.M. Romani, Biofilm formation at warming temperature: acceleration of microbial colonization and microbial interactive effects, Biofouling, 27 (2011) 59-71. [35] R.J. Stevenson, M.L. Bothwell, R.L. Lowe, Algal ecology: Freshwater benthic ecosystems, in, Academic Press, Inc. San Diego, CA, 1996.

[36] K. Krammer, H. Lange-Bertalot, Bacillariophyceae 2/4 Teil: Achnanthaceae. Kritische Ergänzungen zu Navicula (Lineolatae) und Gomphonema., G. Fischer Verlag., Stuttgart, 1991. [37] J.R. Díaz-Ramos, Indice de la microflora marina de Venezuela: diatomeas, dinoflagelados y cocolitofóridos, Revista de Biología Tropical 48 (2000) 897-918. 
Author-produced version of the article published in Journal of Hazardous Materials, vol. 334, 2017, 223-232 The original publication is available at http://www.sciencedirect.com/

doi : 10.1016/j.jhazmat.2017.04.016

[38] A.R. Sherwood, Bibliographic checklist of the non-marine algae of the Hawaiian Islands, Records of the Hawaii Biological Survey for 2003. Bishop Museum Occassional Papers Series, 80 (2004) 1-23. [39] M. Bottin, J. Soininen, D. Alard, J. Rosebery, Diatom cooccurrence shows less segregation than predicted from niche modeling, PLoS ONE, 11 (2016) e0154581.

[40] J. Heino, J. Soininen, Assembly rules and community models for unicellular organisms: patterms in diatoms of boreal streams, Freshwat. Biol., 50 (2005) 567-577.

[41] A. Oukarroum, F. Perreault, R. Popovic, Interactive effects of temperature and copper on photosystem II photochemistry in Chlorella vulgaris, Journal of Photochemistry and Photobiology B: Biology, 110 (2012) 9-14.

[42] K. Sbihi, O. Cherifi, M. Bertrand, A. El Gharmali, Biosorption of metals ( $\mathrm{Cd}$, Cu and $\mathrm{Zn}$ ) by the freshwater diatom Planothidium lanceolatum: a laboratory study, Diat. Res., 29 (2014) 55-63.

[43] S. Yachi, M. Loreau, Biodiversity and ecosystem productivity in a fluctuating environment: The insurance hypothesis, Proceedings of the National Academy of Sciences, 96 (1999) 1463-1468. 
Author-produced version of the article published in Journal of Hazardous Materials, vol. 334, 2017, 223-232 The original publication is available at http://www.sciencedirect.com/

doi : 10.1016/j.jhazmat.2017.04.016

\section{$\underline{\text { Tables }}$}

Table 1. Average $( \pm S D, n=16)$ physical and chemical conditions in all mesocosms over the 6 weeks of the experiment, before and after each water change.

\begin{tabular}{|l|c|}
\hline Parameter & Measured values \\
\hline $\mathrm{pH}$ & $8.6 \pm 0.4$ \\
\hline Conductivity $\left(\mu \mathrm{S} \cdot \mathrm{cm}^{-1}\right)$ & $341.8 \pm 15.0$ \\
\hline Dissolved oxygen $\left(\mathrm{mg} \cdot \mathrm{L}^{-1}\right)$ & $9.8 \pm 1.0$ \\
\hline $\mathrm{NO}_{3}\left(\mathrm{mg} \cdot \mathrm{L}^{-1}\right)$ & $17.0 \pm 0.7$ \\
\hline $\mathrm{NO}_{2}\left(\mathrm{mg} \cdot \mathrm{L}^{-1}\right)$ & $0.05 \pm 0.04$ \\
\hline $\mathrm{NH}_{4}\left(\mathrm{mg} \cdot \mathrm{L}^{-1}\right)$ & $0.02 \pm 0.02$ \\
\hline $\mathrm{PO}_{4}\left(\mathrm{mg} \cdot \mathrm{L}^{-1}\right)$ & $0.19 \pm 0.03$ \\
\hline $\mathrm{DOC}\left(\mathrm{mg} \cdot \mathrm{L}^{-1}\right)$ & $0.93 \pm 0.09$ \\
\hline $\mathrm{SiO}_{2}\left(\mathrm{mg} \cdot \mathrm{L}^{-1}\right)$ & $7.3 \pm 0.7$ \\
\hline
\end{tabular}


Table 2. Predictions of the effects of copper exposure and temperature, alone and in interaction, on global estimates of diatom biomass and diversity, and on the most abundant species, using linear mixed-effects models. Positive $(+)$ or negative (-) effects of treatments (ns: not significant) or mode of interaction are shown.

\begin{tabular}{|c|c|c|c|c|}
\hline & Meaningful factor & df & Effect & $p$ \\
\hline \multicolumn{5}{|l|}{ Global estimates } \\
\hline Diatom biomass $\left(\mu \mathrm{g} \cdot \mathrm{cm}^{-2}\right)$ & $\mathrm{Cu}$ & 102 & - & 0.0349 \\
\hline Species richness & Cu x Temperature & 65 & Antagonistic & 0.0266 \\
\hline Shannon diversity & Cu x Temperature & 65 & Antagonistic & 0.0329 \\
\hline Turnover (\%) & Temperature & 58 & + & 0.0128 \\
\hline \multicolumn{5}{|l|}{ Diatom taxa (log-transformed relative abundances) } \\
\hline Achnanthidium exiguum (Grunow) Czarnecki & $\begin{array}{c}\mathrm{Cu} \\
\text { Temperature }\end{array}$ & $\begin{array}{l}65 \\
65\end{array}$ & $\begin{array}{l}+ \\
+\end{array}$ & $\begin{array}{c}0.0008 \\
<0.0001\end{array}$ \\
\hline $\begin{array}{l}\text { Achnanthidium minutissimum (Kützing) } \\
\text { Czarnecki }\end{array}$ & \multicolumn{4}{|c|}{ ns } \\
\hline $\begin{array}{l}\text { Amphora copulata (Kützing) Schoeman \& } \\
\text { Archibald }\end{array}$ & Cu x Temperature & 65 & Antagonistic & 0.0163 \\
\hline Amphora pediculus (Kützing) Grunow & Temperature & 65 & - & 0.0176 \\
\hline Cocconeis euglypta Ehrenberg & $\mathrm{Cu}$ & 65 & + & 0.0096 \\
\hline Cocconeis placentula Ehrenberg & $\mathrm{Cu}$ & 65 & + & 0.0001 \\
\hline Eolimna minima (Grunow) Lange-Bertalot & Cu x Temperature & 65 & Antagonistic & 0.0237 \\
\hline Fragilaria capucina Desmazières & \multicolumn{4}{|c|}{ ns } \\
\hline Gomphonema parvulum (Kützing) Kützing & Cu x Temperature & 65 & Antagonistic & 0.0249 \\
\hline Navicula gregaria Donkin & Cu x Temperature & 65 & Antagonistic & 0.0008 \\
\hline Navicula lanceolata (Agardh) Ehrenberg & \multicolumn{4}{|c|}{ ns } \\
\hline Nitzschia inconspicua Grunow & Temperature & 65 & - & 0.0132 \\
\hline Nitzschia linearis (Agardh) W.M.Smith & Cu x Temperature & 65 & Antagonistic & 0.0009 \\
\hline Nitzschia palea (Kützing) W.Smith & Temperature & 65 & - & 0.0168 \\
\hline $\begin{array}{l}\text { Planothidium frequentissimum (Lange- } \\
\text { Bertalot) Lange-Bertalot }\end{array}$ & Cu x Temperature & 65 & Antagonistic & 0.0472 \\
\hline $\begin{array}{l}\text { Planothidium lanceolatum (Brébisson ex } \\
\text { Kützing) Lange-Bertalot }\end{array}$ & Cu x Temperature & 65 & Antagonistic & 0.0286 \\
\hline $\begin{array}{l}\text { Reimeria sinuata (Gregory) Kociolek \& } \\
\text { Stoermer }\end{array}$ & $\mathrm{Cu}$ & 65 & + & 0.0008 \\
\hline $\begin{array}{l}\text { Rhoicosphenia abbreviata (C.Agardh) Lange- } \\
\text { Bertalot }\end{array}$ & Cu x Temperature & 65 & Antagonistic & 0.0105 \\
\hline Surirella angusta Kützing & Temperature & 65 & - & 0.008 \\
\hline
\end{tabular}




\section{Figures}
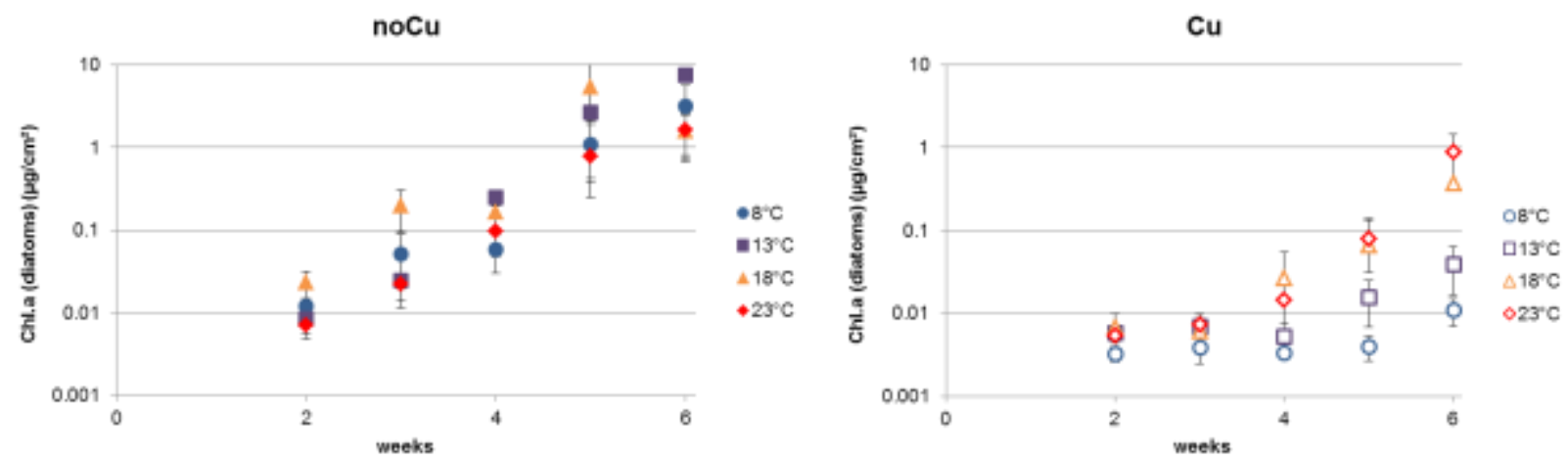

Figure 1. Time course of chlorophyll a (Chl.a) concentrations related to diatoms (mean $\pm \mathrm{SD}, \mathrm{n}=3$ ) in control (noCu) and Cu-exposed mesocosms, incubated at four increasing temperature levels. 
Author-produced version of the article published in Journal of Hazardous Materials, vol. 334, 2017, 223-232 The original publication is available at http://www.sciencedirect.com/

doi : 10.1016/j.jhazmat.2017.04.016
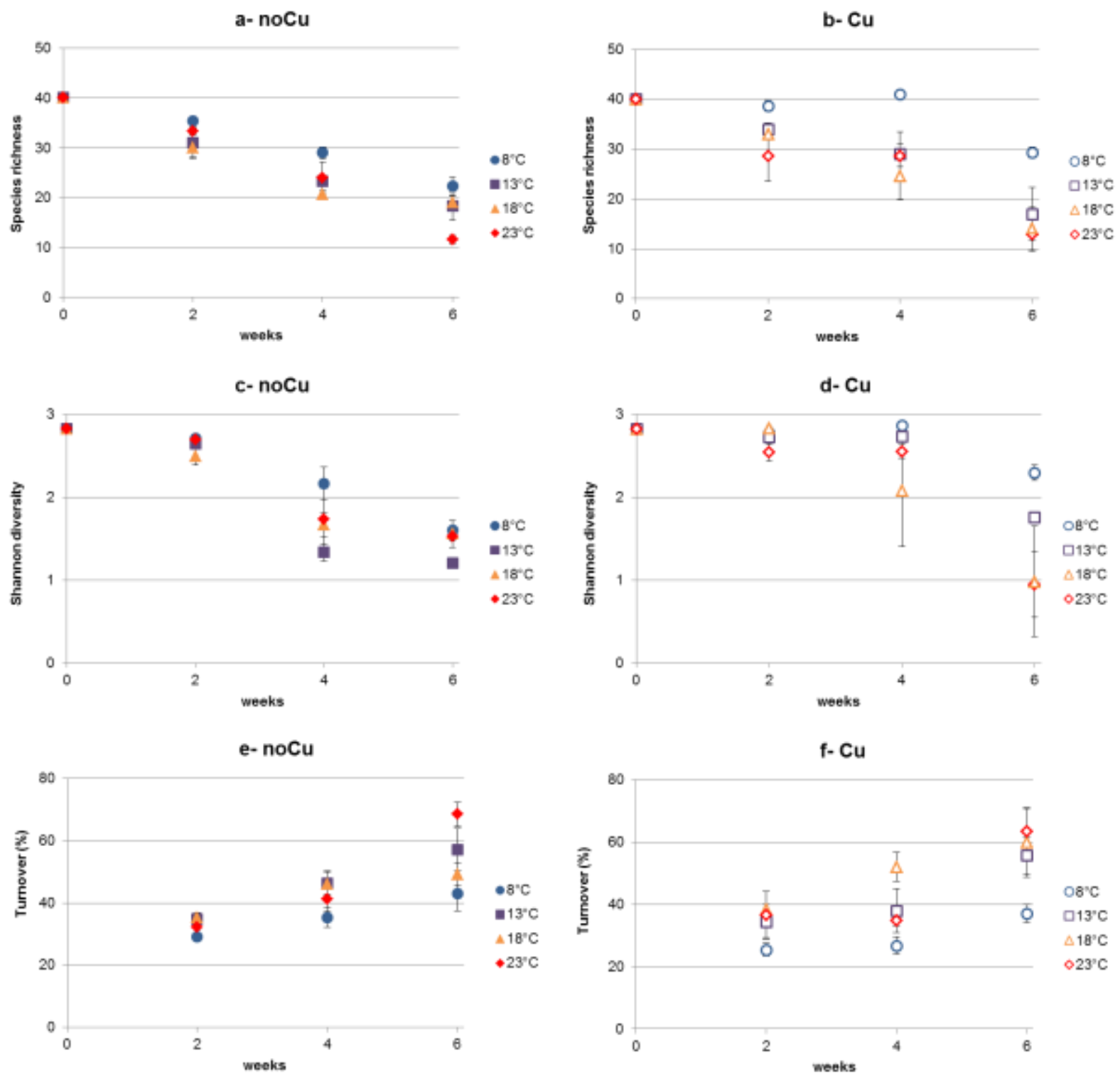

Figure 2. Average response $( \pm S D, n=3)$ of species richness $(a, b)$, Shannon diversity index $(c, d)$ and species turnover (e,f) over the course of the experiment in control (noCu: $a, c, e)$ and Cu-exposed (b, d, f) mesocosms, incubated at four increasing temperature levels. Week 0 corresponds to the initial composition found in the inoculum. 


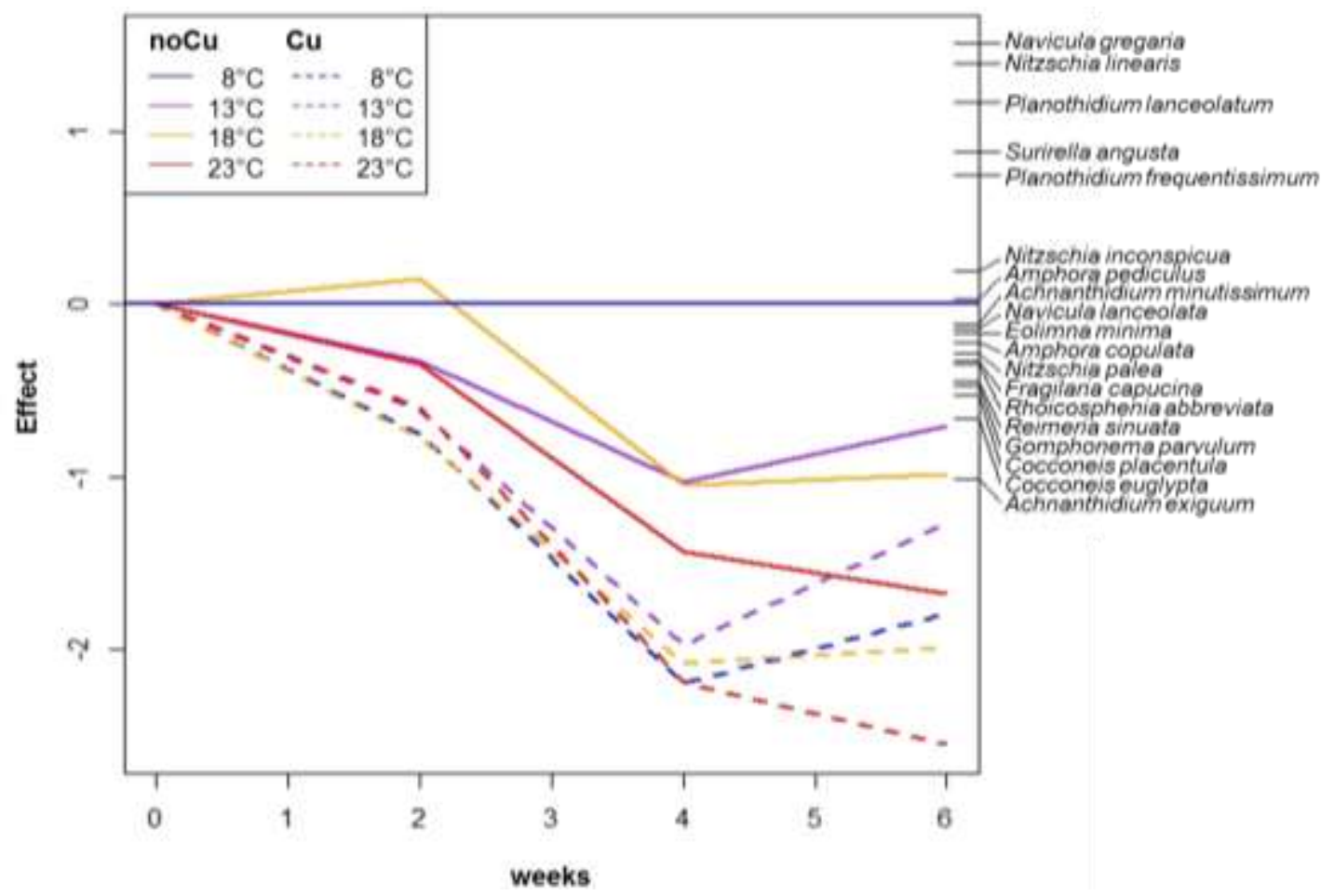

Figure 3. Changes in diatom community composition over time, compared with the noCu treatment at $8{ }^{\circ} \mathrm{C}$ as a reference trajectory. The principal response curve $(\mathrm{PRC})$ displays time on the $X$-axis and effect (canonical coefficient of the analysis relative to noCu-8) on the left $Y$-axis. On the right $Y$-axis are plotted the scores of the 19 most abundant species. 
noCu

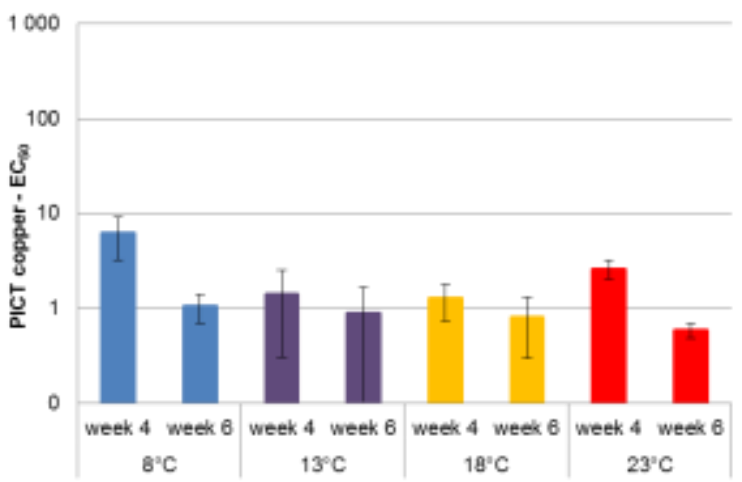

$\mathrm{Cu}$

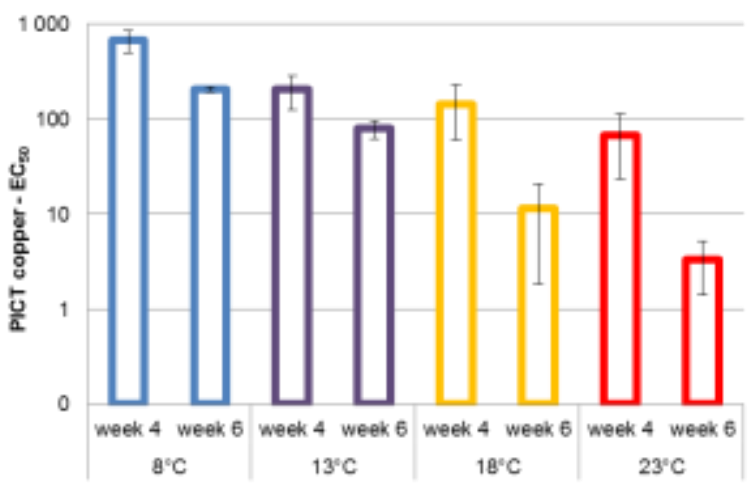

Figure 4. PICT responses of periphytic communities for copper after 4 and 6 weeks in noCu (a) and $\mathrm{Cu}$ (b) treatments. $\mathrm{EC}_{50}$ values (mean $\pm \mathrm{SD}, \mathrm{n}=3$; in $\mu \mathrm{gCu} \cdot \mathrm{L}^{-1}$ ) are based on chlorophyll a fluorescence inhibition, normalized by algal biomass (total chlorophyll a). Note the logarithmic scale on the $Y$-axis. 
Author-produced version of the article published in Journal of Hazardous Materials, vol. 334, 2017, 223-232

The original publication is available at http://www.sciencedirect.com/

doi : 10.1016/j.jhazmat.2017.04.016

Appendix A: Changes in average relative abundance $(\%, n=3)$ of the most abundant species (accounting for $>5 \%$ in at least one sample) over the 6 -week experiment, in the 8 treatments.

Species abbreviations: ADEG: Achnanthidium exiguum (Grunow) Czarnecki, ADMI: Achnanthidium minutissimum (Kützing) Czarnecki, APED: Amphora pediculus (Kützing)

Grunow, CPLA: Cocconeis placentula Ehrenberg var. placentula, EOMI: Eolimna minima (Grunow) Lange-Bertalot, NLIN: Nitzschia linearis (Agardh) W.M.Smith var. linearis, NPAL: Nitzschia palea (Kützing) W.Smith, PLFR: Planothidium frequentissimum (Lange-Bertalot) Lange-Bertalot, PTLA: Planothidium lanceolatum (Brébisson ex Kützing) LangeBertalot, RABB: Rhoicosphenia abbreviata (C. Agardh) Lange-Bertalot, RSIN: Reimeria sinuata (Gregory) Kociolek \& Stoermer.

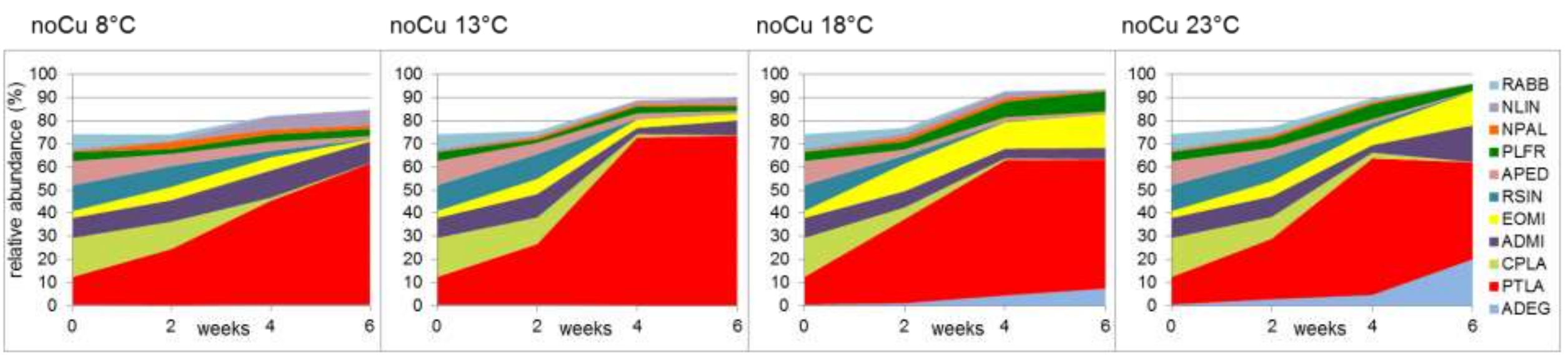

\section{$\mathrm{Cu} 8^{\circ} \mathrm{C}$}

\section{$\mathrm{Cu} 13^{\circ} \mathrm{C}$}

\section{$\mathrm{Cu} 18^{\circ} \mathrm{C}$}

\section{$\mathrm{Cu} 23^{\circ} \mathrm{C}$}
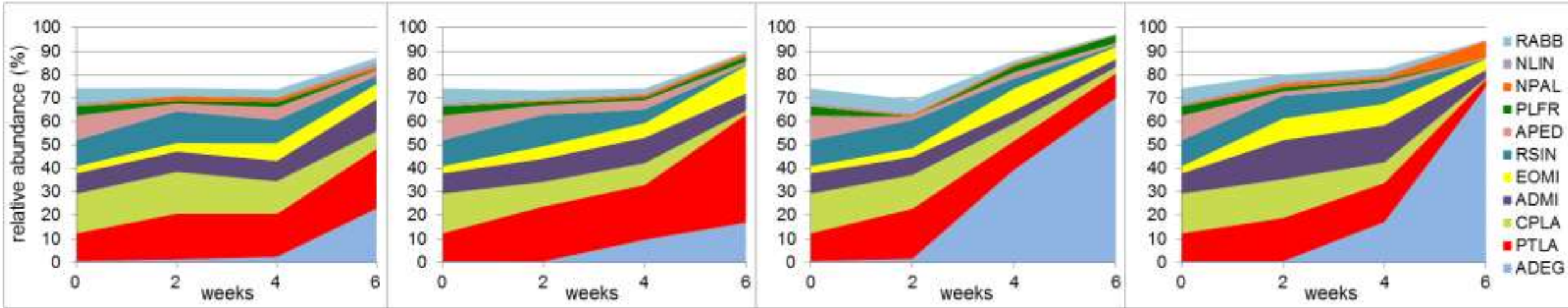
Appendix B: Cluster based on the logtransformed abundances of the species found at more than $2 \%$ relative abundances, with Bray-Curtis distance and complete linkage (farthest neighbor), under R environment, package vegan.

Community compositions that are compared to 4-week average structure of this experiment are collected from previous surveys in the Morcille catchment basin (references listed below). Samples are coded as follows: Site_Date, where Sites are $\mathrm{J}=$ Saint Joseph, upstream pristine site; $\mathrm{E}=$ Saint Ennemond, downstream impacted site; and Date is given as month and year of sampling. Samples from the present experiment are highlighted in red boxes. Note that J_Feb12 corresponds to the inoculum used in this study.

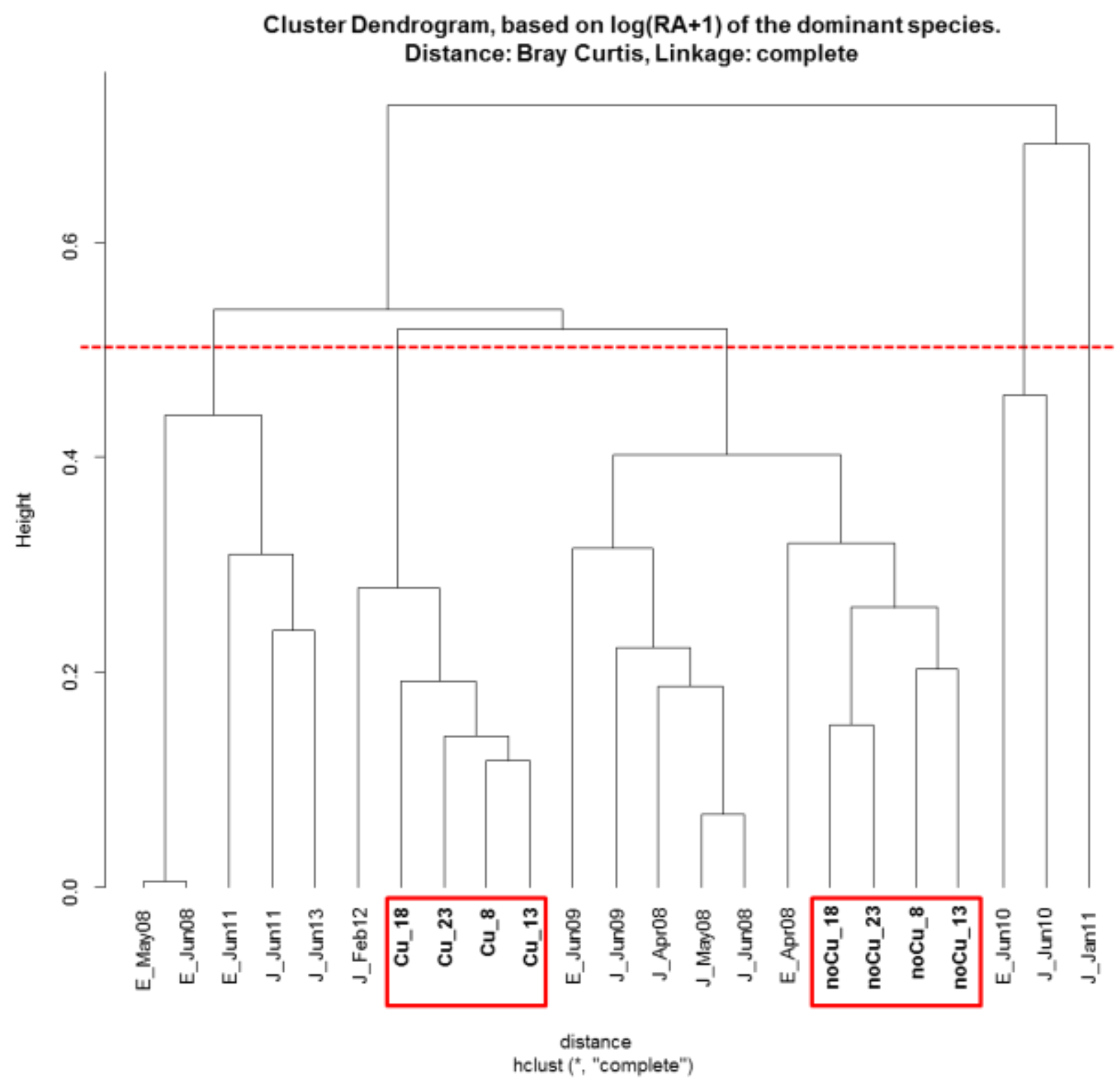

References used:

Morin, S., Pesce, S., Tlili, A., Coste, M., Montuelle, B., 2010. Recovery potential of periphytic communities in a river impacted by a vineyard watershed. Ecological Indicators 10, 419-426. 
Pesce, S., Lissalde, S., Lavieille, D., Margoum, C., Mazzella, N., Roubeix, V., Montuelle, B., 2010. Evaluation of single and joint toxic effects of diuron and its main metabolites on natural phototrophic biofilms using a pollution-induced community tolerance (PICT) approach. Aquatic Toxicology 99, 492-499.

Roubeix, V., Mazzella, N., Schouler, L., Fauvelle, V., Morin, S., Coste, M., Delmas, F., Margoum, C., 2011. Variations of periphytic diatom sensitivity to the herbicide diuron and relation to species distribution in a contamination gradient: implications for biomonitoring. Journal of Environmental Monitoring 13, 1768-1774.

Morin, S., Lambert, A.-S., Artigas, J., Coquery, M., Pesce, S., 2012. Diatom immigration drives biofilm recovery after chronic copper exposure. Freshwater Biology 57, 1658-1666.

Morin, S., Pesce, S., Kim-Tiam, S., Libert, X., Coquery, M., Mazzella, N., 2012. Use of polar organic chemical integrative samplers to assess the effects of chronic pesticide exposure on biofilms. Ecotoxicology 21, 1570-1580.

Kim Tiam, S., Morin, S., Pesce, S., Feurtet-Mazel, A., Moreira, A., Gonzalez, P., Mazzella, N., 2014. Environmental effects of realistic pesticide mixtures on natural biofilm communities with different exposure histories. Science of the Total Environment 473-474, 496-506.

Foulquier, A., Morin, S., Dabrin, A., Margoum, C., Mazzella, N., Pesce, S., 2015. Effects of mixtures of dissolved and particulate contaminants on phototrophic biofilms: new insights from a PICT approach combining toxicity tests with passive samplers and model substances. Environmental Science and Pollution Research 22, 4025-4036. 